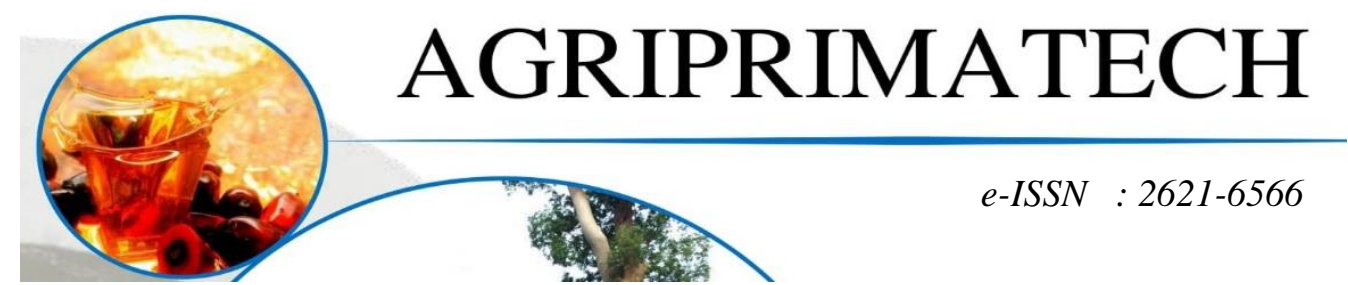

\title{
ANALISIS KELAYAKAN USAHA TERNAK SAPI POTONG SEBAGAI USAHA KELUARGA DI NAGORI SILAMPUYANG KECAMATAN SIANTAR KABUPATEN SIMALUNGUN
}

\author{
MARTUA SIADARI ${ }^{1}$, MARLAN $^{2}$, SANDI JONANDO GIRSANG ${ }^{3}$ \\ 1,2Dosen Program Studi Agribisnis, Fakultas Pertanian, Universitas Simalungun \\ ${ }^{3}$ Mahasiswa Program Studi Agribisnis, Fakultas Pertanian, Universitas Simalungun \\ Email : Sandijonando@yahoo.co.id
}

\begin{abstract}
ABSTRAK
Tujuan penelitian ini adalah untuk mengetahui kelayakan usaha ternak sapi potong yang berada di Nagori Silampuyang. Penelitian ini mendapatkan rata-rata total biaya yang dikeluarkan oleh 27 peternak sebesar Rp.23.808.331, total penerima rata-rata sebesar Rp.99.562.111 dan rata-rata pendapatan bersih yang diperoleh para peternak sebesar Rp.75.753.708. Pada penelitian ini didapatkan kelayakan usaha ternak sapi potong didaerah penelitian sebesar 4,182 yang artinya setiap biaya yang dikeluarkan 1 rupiah akan menghasilkan penerimaan sebesar 4,182 rupiah, dan usaha ternak sapi potong di Nagori Silampuyang Kecamatan Siantar Kabupaten Simalungun dapat dikatakan menguntungkan dan layak dikembangkan sesuai dengan $\mathrm{R} / \mathrm{C}$ sebesar 4,182 > 1 .
\end{abstract}

Kata kunci : Kelayakan, Usaha, Ternak, Sapi, Potong

\section{PENDAHULUAN}

Indonesia merupakan negara agribisnis dimana mata pencarian penduduknya sebagian besar adalah peduduknya yang memberikan pangan bagi sebagian besar penduduknya. Salah satu kegiatan itu adalah kegiatan usaha ternak yang secara umum memilik beberapa kelebihan seperti seba gai sumber pendapatan untuk manfaatkan limbah pertanian, sebagai penghasil daging dan susu, kotorannya dapat di man faatkan sebagai sumber pupuk organik dan kulitnya juga me miliki nilai ekonomi yang tinggi (Abidin, 2002).

Hartono (2012) menjelaskan bahwa "peternak memelihara ternak sapi sebagai bagian untuk mengoptimalkan sumber daya keluarga peternak dalam menghasilkan manfaat dalam bentuk anakan sapi, kenaikan nilai ternak dan kotoran ternak untuk pupuk". Dengan potensi sumber daya alam yang sangat mendukung dalam memenuhi kebutuhan pokok ternak. Inilah yang menjadikan peluang baru dalam meningkatkan ekonomi keluarga melalui usaha ternak sapi.

Tabel 1. Populasi Sapi Potong di Sumatera Utara/kg (2018-2019)

\begin{tabular}{cc}
\hline Tahun & Populasi Sapi Potong \\
\hline 2018 & 982.963 \\
2019 & 1.009 .301 \\
\hline
\end{tabular}

Sumber; Badan Pusat statistik ,2020

Dari Tabel 1. Dapat diketahui bahwa populasi sapi potong di Sumatera Utara mengalami peningkatan. Populasi sapi potong pada tahun 2018 yaitu sebesar 982.963 populasi dan pada tahun 2019 
mengalami peningkatan yang yaitu sebesar 1.009.301.

Berdasarkan data dari kementrian pertanian(2020) pro duksi daging sapi di Provinsi Sumatera Utara mengalami peningkatan. Produksi daging sapi Provinsi Sumatera Utara dapat dilihat pada tabel 2.

Tabel 2. Produksi Daging Sapi Provinsi Sumatera Utara 2018-2019

\begin{tabular}{cc}
\hline Tahun & Populasi Sapi Potong \\
\hline 2018 & 15.240 .326 \\
2019 & 15.723 .561 \\
\hline
\end{tabular}

Sumber: Badan Pusat Stastik,2020

\section{METODE PENELITIAN}

Tempat pelaksanaan peneli tian ini adalah di Nagori Silam puyang Kecamatan Siantar Kabupaten Sima lungun. Pemi lihan lokasi dilakukan secara sengaja dengan pertimbangan bahwa terdapat banyak populasi sapi potong dalam skala keluar ga di Nagori Silampuyang Kecamatan Siantar Kabupaten Sima lungun. Metode yang digunakan dalam penen tuan lokasi menggu nakan metode purposive samp ling yaitu teknik penentu sampel dengan tujuan terten tu sesuai dengan topik penelitian.Perencanaan penelitian dilaku kan mengetahui jumlah perter nak sapi yang di mulai pada Bulan April - Mei 2020.

\section{Populasi dan Sampel}

Populasi adalah peternak sapi poto ng yang secara langsung terlibat dalam kegiatan peningkatan populasi sapi potong. Populasi dalam pene litian ini berjumlah 27 peternak di Nagori Silampuyang Kecamatan Siantar Kabupaten Simalungun.

Sampling jenuh adalah teknik penentuan sampel bila semua anggota populasi digunakan sebagai sampel. Hal ini sering dilakukan bila jumlah populasinya relatif kecil, kurang dari 30 orang. Sampel jenuh disebut juga dengan istilah sensus, dimana semua anggota populasi dijadikan sampel (Sugiyono,2001). Dalam penelitian ini seluruh populasi dijadikan sampel penelitian yaitu sebanyak 27 responden.

\section{Metode Pengumpulan Data}

Data yang dipakai dalam penelitian ini adalah data kualitatif. Data kualitatif adalah data yang dinyatakan dalam bentuk kata, kalimat, dan gambar.

Sumber data dalam penelitian ini terdiri dari dua yaitu: Data primer adalah sumber data penelitian yang diperoleh secara langsung dari sumber aslinya yang berupa wawancara, juga pendapat dari individu atau kelompok (orang) maupun hasil observasi dari suatu obyek, kejadian atau hasil pengujian (benda).dalam penelitian ini peneliti yang menjadi data primer yaitu para peternak sapi di Nagori Silampuyang Kecamatan Siantar Kabupaten Simalungun.

Data sekunder adalah sumber data penelitian yang diperoleh melalui media perantara atau secara tidak langsung yang berupa buku, catatan, bukti yang telah ada, atau arsip baik yang dipublikasikan maupun yang tidak dipublikasikan secara umum,sebagai pelengkap data primer.

\section{Metode Analisis Data}

Analisis Keuntungan

Menurut Pura (2011), Penda patan adalah banyaknya output dikalikan harganya Biaya produksi adalah input dikalikan harganya, maka tingkat keuntungan dari usaha peternakan dihitung dengan persama an sebagai berikut:

$\mathrm{I}=\mathrm{TR}-\mathrm{TC}$

$I=P y . Y-(P x 1 . X 1+P x 2 . X 2+P x 3 . X 3)$

Keterangan:

I = Tingkat keuntungan

$Y=$ Output produksi (sapi).

Py = Harga jual sapi (Rp/ekor)

Px3 = Harga tenaga kerja (orang/hari)

Px1 = Harga bakalan (ekor)

$\mathrm{X} 3$ = Jumlah tenaga kerja (orang)

$\mathrm{X} 1=$ Jumlah bakalan (ekor)

Px2 = Harga pakan hijauan (ikat)

X2 = Jumlah pakan (ikat)

Usaha peternakan sapi potong menguntungka apabila Keuntungan $>0$, dan sebaliknya apabila Keuntu ngan $<0$, 
maka usaha peternakan sapi potong tersebut tidak mengun tungkan.

\section{Analisis Kelayakan Usaha}

Revenue Cost Ratio (R/C)

Menurut Rahardi dan Harto no (2003), R/C adalah perbandingan antara penerimaan dengan biaya-biaya yang dikeluarkan selama pro ses produksi hingga menghasil kan produk dan akan usaha menguntung kan apabila nilainya $>1$, apabila nilainya $=$ 1 dikatakan impas, dan apabila nilainya < 1 dapat dikatakan tidak layak atau tidak menguntung kan.

Rumus :

$$
\begin{aligned}
& \mathrm{R} / \mathrm{C} \\
& =\frac{\text { Total penerimaan penjualan produk }}{\text { Total biaya }}
\end{aligned}
$$

\section{HASIL DAN PEMBAHASAN Deskripsi Lokasi Penelitian}

Nagori Silampuyang memi liki garis letak koordinat pada $02^{\circ} 54^{\prime} 28^{\prime \prime}$ LU dan $099^{\circ} 04^{\prime}$ 47" BT dan berada pada keting gian 402 mdpl. Nagori Silam punyang berada dalam cakupan Kecamatan Siantar Kabupaten Simalungun yang memiliki luas wilayah $10.40 \mathrm{Km}^{2}$.

\section{Keadaan Tata Guna Lahan}

Lahan merupakan permu kaan bumi yang digunakan manu sia untuk memenuhi kebutuhan produksi, pemukiman dan fasilitas lainnya. Berdasarkan hasil yang diperoleh dari informasi, keadaan tata guna lahan di desa Tumorang bahwa penggunaan lahan di Nagori Silampuyang digunakan sebagai lahan sawah seluas $92 \mathrm{Ha}$ dan lahan kering $64 \mathrm{Ha}$ sedangkan lahan yang dipergunakan dalam cakupan beragam seluas $858 \mathrm{Ha}$.

\section{Keadaan Penduduk}

Keadaan penduduk dalam suatu wilayah merupakan gambaran dalam konteks potensi suatu wilayah sebagai sumber daya manusia yang dapat mengolah sumber daya alam untuk memenuhi kebutuhan serta pengembangan wilayah tersebut. Jumlah penduduk di Nagori
Silampuyang 4234 jiwa, terdiri dari 2.301 jiwa laki-laki dan 1.933 jiwa perempuan. Bahwa sebagian penduduk di Nagor Silampuyang pada usia $(<1$ Tahun) yaitu 42 jiwa, usia (2-4

Tahun) yaitu 114 jiwa, usia (5-14 Tahun) yaitu 689 jiwa,usia (15-39 Tahun) yaitu 1762 jiwa,usia (40-64 Tahun) yaitu 1229 jiwa, dan usia (>65 Tahun) yaitu 384 jiwa.

\section{Perekonomian}

Mata pencaharian utama penduduk di Nagori Silampuyang adalah Karyawan di lembaga Pemerintahan Selain itu sebagian masyarakat berprofesi sebagai PNS, peternak, buruh tani, pedagang, bidan swasta, pengusaha kecil, karyawan swasta, dan pekerjaaan lainnya. Mata pencaharian penduduk didaerah penelitian sebagian besar adalah pete rnak $(11,37 \%)$ yang pada umumnya mengusahakan ternak sapi, kambing, dan ternak unggas. Persentase terke cil adalah Bidan Swasta yaitu seba nyak 6 jiwa $(0,30 \%)$

\section{Karakteristik Peternak Sampel}

Peternak sampel yang dimaksud disini adalah seluruh petani padi sawah yang memiliki usaha ternak sapidan juga menjualnya dalam bentuk ekor yang berada di Nagori Silampuyang. Karakteristik peternak sampel dalam penelitian ini terdiri dari umur peternak, tingkat pendidikan peternak, lama beternak, jumlah tanggungan keluarga.

Bahwa di umur antara 41-60 tahun yang mendominasi pelaku ternak sapi potong di Nagori Silampuyang sebanyak 21 responden dengan persentase $77,78 \%$. Pada tabel diatas menyatakan peternak sapi potong di Nagori Silampuyang hanya laki-laki yang melakukan dengan nilai persentase mutlak $100 \%$.

Tingkat pendidikan peternak pada tingkat SMA yang memiliki dominasi sebanyak 20 responden dengan persentase $74,07 \%$. Dan tingkat pendidikan SD sebanyak 2 responden dengan persentase $7,41 \%$.

Tabel 3. Pengalaman berternak pada usaha ternak sapi potongdiNagori Silampuyang tahun 2020 


\begin{tabular}{cccc}
\hline & $\begin{array}{c}\text { Lama } \\
\text { Pengalaman } \\
\text { No }\end{array}$ & $\begin{array}{c}\text { Jumlah } \\
\text { ternak }\end{array}$ & $\begin{array}{c}\text { Persentase } \\
(\%)\end{array}$ \\
\hline 1 & $1-10$ tahun & 21 & 77,78 \\
2 & $11-20$ tahun & 6 & 22,22 \\
\hline & Jumlah & 27 & 100 \\
\hline
\end{tabular}

Sumber: Data primer diolah 2020

Pengalaman beternak tiap peternak yaitu pada interval 1-10 tahun ada sebanyak 21 responden dengan persentase $77,78 \%$, dan pada interval 11-20 tahun ada sebanyak 6 responden dengan persentase $22,22 \%$.

\section{Sistem Pemeliharaan Usaha Ternak Sapi di Daerah Penelitian}

Di daerah penelitian, mayoritas peternak sapimasih menggunakan cara yang sederhana yaitu bentuk pemeliharaan dengan tata pelaksanaannya tidak terprogram dengan baik, kandangnya hanya dibangun dengan sekedarnya saja hanya untuk tempat berlindung dari teriknya matahari diwaktu siang dan untuk melindungi ternak dari udara yang dingin diwaktu malam, dalam pengembalaannya ternak sapi potong hanya dilepas di lapangan, hamparan padang rumput, dan di lahan perkebunan sawit yang sudah besar yang agak jauh dari pemukiman warga.

Usaha ternak sapi potong yang dilakukan secara sederhana tidak terlalu memikirkan hasil produksinya karena peternak menganggap tingkat usaha seperti ini masih menonjolkan kepentingan keluarga, serta aspek kepuasan dipandang lebih utama, karena peternak dianggap telah memiliki tabungan berbentuk ternak yang dapat dijual pada saat dibutuhkan dalam keadaan tidak terduga.

\section{Perkandangan}

Di daerah penelitian, kan dang dibangun dengan arah utara - selatan, agar sinar matahari pada waktu pagi hari tetap masuk kan dang dan tidak begitu panas. Sinar matahari pada pagi hari mengan dung sinar ultraviolet sangat pen ting untuk membasmi kuman dan membantu pembentukan vitamin pada ternak sapi potong. Perkanda ngan sapi dibangun berdekatan dengan rumah penduduk atau pe ternak agar para peternak dapat lebih mudah mengawasi usaha ternaknya tersebut.

\section{Penyediaan Bibit}

Para peternak di daerah penelitian memilih jenis bibit ternak sapi potong lokal. Perka winan antara induk dan pejantan terjadidilokasi pemeliharaan mau pun di lokasi penggembalaan tan pa diawasi dan ditangani secara khusus. Umumnya jenis bibit ternak sapi potong sebagai pejan tan adalah jenis sapi lokal, seperti sapi rambon atau sapi aceh.

\section{Pemberian pakan hijauan}

Ternak sapi potong di daerah penelitian dapat mem peroleh pakan hijauan di lokasi penggembalaan, ternak sapi poto ng digiring dan ditunggui oleh penggembala sampai waktunya pulang sore hari atau setelah ma tahari terbenam. Jenis pakan hijau an yang diberikan untuk ternak sapi potong tersebut adalah jenis rumput lapangan dan rumput gaja han tetapi kebanyakan peternak masih mengambil pakan rumput tersebut dari padang rumput atau dari ladang ketika sapi telah siap diangon.

\section{Pemberian pakan konsentrat}

Pakan konsentrat sering disebut makanan tambahan atau makanan penguat yang sangat berguna bagi ternak sapi potong, terutama ternak yang sedang hamil atau sedang menyusui untuk merangsang air susu yang baik dan bagi ternak yang dalam masa pertumbuhan, karena pemberian bahan konsentrat dapat menambah nafsu makan, contoh bahan bahan konsentrat yaitu seperti dedak padi, bungkil kelapa sawit, tepung jagung, ampas tahu, kulit buah kakao, singkong, ubi jalar, tepung terigu dan lain sebagainya.

\section{Pemberian air minum}

Pemberian air minum untuk sapi potong di daerah penelitian ini diberikan minum 
dengan air garam atau air gula merah dengan asam jawa sebagai jamu bagi ternak yang baru beranak dengan secukupnya dan dilakukan pada sore hari setelah sapi potong pulang dari penggembalaan. Sumber air minum untuk ternak sapi potong tersebut berasal dari air sumur di dekat pekandangan sapi potong tersebut dan di daerah penelitian ketersediaan air bersih masih sangat mencukupi.

\section{Kebersihan sapi potong dan kandang}

Di daerah penelitian kebersihan kandang dilakukan dengan cukup baik, dimana kebersihan kandang dilakukan setiap hari sekali yaitu pada siang hari sampai dengan so re hari pada saat sapi potong seda ng digembalakan. Kebersihan kan dang sangat perlu dilakukan untuk menunjang kesehatan sapi potong, selain untuk menjaga kelembaban kandang, hal tersebut juga dilaku kan untuk menghindari adanya lalat atau serangga lain yang seri ng terdapat pada kandang ternak sapi potong tersebut.

\section{Pemberian obat - obatan}

Peternak sapi potong yang berada di daerah penelitian, pada umumnya masih memberikan obat - obatan alami bila ternak sapi potong mereka terserang penyakit. Peternak memberikan obat oba tan alami untuk menyembuhkan penyakit yang sering timbul seper ti diare dan masuk angin. Pembe rian obat pada ternak sapi potong juga dapat dilakukan secara sunti kan dengan bantuan dokter hewan atau juga dapat langsung diberi kan melalui mulut ternak sapi oleh bantuan peternak sapi potong tersebut, bila sapi potong menderi ta penyakit diare atau masuk angin umumnya peternak memberikan obat suntikan teramisin atau dengan memberi makan obat pil sambi dan lain sebagainya.

\section{Pendapatan Usaha Ternak Sapi Potong}

Pendapatan usaha yang diperoleh dari ternak sapi adalah selisih antara total penerimaan usaha ternak sapi potong dengan total biaya produksi yang dikeluar kan peternak selama proses usaha pemeliharaan atau kegiatan budi daya ternak sapi tersebut.

\section{Biaya produksi usaha ternak sapi potong}

Peternak hanya menggunakan tenaga kerja dalam keluarga, kemudian biaya tambahan yang meliputi biaya, biaya listrik dan BBM. Biaya - biaya produksi yang dikeluarkan oleh peternak. Rataan biaya produksi usaha ternak sapi per peternak pertahun mencakup biaya penyusutan kandang sebesar Rp.309.753,09 atau $1,30 \%$ dari seluruh to tal biaya produksi, dan biaya penyusutan peralatan sebesar Rp.223.021,74 atau 0,94\% da ri seluruh total biaya produksi, kemudian biaya Penerimaan Usaha Ternak Sapi. Penerimaan adalah penjum lah dari pertambahan nilai ternak, hasil penjualan ternak sapi dan hasil penjualan kotoran ternak dalam satu proses produksi ternak sapi tersebut selama satu tahun. Rataan penerimaan usaha ternak sapi yang diperoleh peternak dapat dilihat pada Tabel berikut ini:

Tabel 4. Rata-rata Penerimaan pada Usaha Ternak Sapi Potong di Nagori

Silampuyang (Rp/tahun/petern ak) Tahun 2020.

\begin{tabular}{rll}
\hline No. & Uraian & $\begin{array}{l}\text { Jumlah } \\
\text { Penerimaan }(\mathrm{Rp})\end{array}$ \\
\hline & $\begin{array}{l}\text { Nilai } \\
\text { Pertambahan }\end{array}$ \\
1 & $\begin{array}{l}\text { Ternak } \\
\text { Penjualan }\end{array}$ \\
2 & Sapi Potong & 13.940 .740 \\
\hline & & 99.562 .111 \\
\hline
\end{tabular}

Rataan pertambahan nilai ternak sapi potong yang diperoleh peternak didaerah penelitian ada lah sebesar Rp.85.620.370 perta hun. Rataan penjualan sapi potong sebesar Rp.13,940.740 pertahun.

Rataan total penerimaan peternak dari usaha ternak sapi potong terse but adalah 
sebesar Rp. 99.562.111 pertahun per peternak. Biaya obat-obatan sebesar Rp.23.704 atau $0,10 \%$ dari total biaya produksi, dan biaya tenaga kerja sebesar Rp.18.925.926 atau $79,49 \%$ dari total biaya produksi usaha ternak sapi. Biaya tenaga kerja dalam usaha ternak sapi tersebut terma suk biaya produktif tidak tunai karena tidak dibayar langsung namun diprhitungkan sebagai biaya produktif dalam mengana lisis pendapatan bersih usaha ter nak sapi.

Biaya-biaya tambahan lain yang terdiri dari total biaya produksi,biaya listrik sebesar Rp.333.333 atau $1.4 \%$ dari total biaya produksi, kemudian biaya BBM sebesar Rp.3.992.593atau 16,77\% dari total biaya produksi. Rata-rata total biaya produksi usaha ternak sapi tersebut sebesar Rp.23.808.331.

\section{Pendapatan Usaha Ternak Sapi Potong}

Pendapatan usaha ternak sapi potong yang diperoleh dari selisih antara total penerimaan usaha ternak sapi dengan total biaya yang dikeluarkan peternak selama proses pemeliharaan sapi tersebut dapat dilihat pada Tabel berikut ini:

Tabel 5. Rata-rata Pendapatan Bersih Usaha Ternak Sapi Potongdi Nagori Silampuyang Tahun 2020 (Rp/tahun/peternak)

\begin{tabular}{llc}
\hline No. & Uraian & Jumlah $(\mathrm{Rp})$ \\
\hline \multirow{3}{*}{1} & Penerimaan & \\
& Usaha Ternak & \\
& Sapi & 99.562 .111 \\
& Total Biaya & \\
& Produksi Usaha & \\
2 & Ternak Sapi & 23.808 .331 \\
\hline \multicolumn{2}{c}{ Pendapatan Bersih } & 75.753 .708 \\
\hline
\end{tabular}

Sumber:Data Primer Diolah 2020

Berdasarkan Tabel diatas dapat diketahui bahwa rataan pene rimaan usaha ternak sapi potong per peternak/tahun adalah sebesar Rp. 99.562.111 dan rataan total biaya produksi sebesar Rp.23.808 .331. Maka rataan pendapatan bersih usaha ternak yang diterima oleh peternak sapi potong adalah sebesar Rp.75.753.708 per peternak/tahun.

\section{Kelayakan Usaha Ternak Sapi Potong}

Tabel 6. Kelayakan Usaha Ternak Sapidi Nagori Silampuyang tahun 2020

\begin{tabular}{rlc}
\hline No & Uraian & Jumlah (Rp) \\
\hline 1 & $\begin{array}{l}\text { Penerimaan } \\
\text { Total Biaya }\end{array}$ & 99.562 .111 \\
2 & Produksi & 23.808 .331 \\
\hline \multicolumn{3}{c}{ R/C } \\
\hline \multicolumn{2}{l}{ Sumber:Data Primer Diolah 2020 }
\end{tabular}

Dari Tabel 11 diatas dapat dilihat bahwa kelayakan usaha tani ternak sapi potong di Nagori Silampuyang Kecamatan Siantar Kabupaten Simalungun memiliki nilai $\mathrm{R} / \mathrm{C}$ sebesar 4,182, yang arti nya setiap 1 rupiah biaya yang dikeluarkan akan menghasilkan 4,182 rupiah. Dengan nilai terse but diatas diketahui bahwa R/C usaha ternak sapi potong di Nago ri Silampuyang lebih besar dari 1 (nilai R/C: $4,182>1$ ) berarti usa ha ternak sapi potong di Nagori Silampuyang Kecamatan Siantar Kabupaten Simalungun mengun tungkan atau dapat disebut usaha tani layak untuk dikembangkan.

\section{KESIMPULAN}

Dari analisis yang telah dilaksanakan pada usaha ternak sapi potong didaerah penelitian maka penulis dapat menyimpulkan bahwa:

Kelayakan usaha ternak sapi potong didaerah penelitian memiliki nilai $\mathrm{R} / \mathrm{C}$ rasio sebesar 4,182 >1, artinya setiap satu ru piah biaya yang dikeluarkan akan menghasilkan 4,182 rupiah. Deng an nilai $\mathrm{R} / \mathrm{C}$ rasio> 1 maka usaha ternak sapi potong di Nagori Sila mpuyang Kecamatan Siantar Kabupaten Simalungun mengun tungkan. Dengan rataan pendapa tan bersih usaha ternak sapi poto ng didaerah penelitian adalah sebe sar Rp.75.753.708 per peternak /tahun. 
Dengan berjalannya pene liti melaksanakan penelitian dike tahui sistem pemeliharaan usaha ternak sapi didaerah penelitian ma sih tergolong sangat sederhana atau tradisional. Hal ini terbukti selama proses berternak sapi poto ng tersebut peternak tidak mem berikan pakan tambahan atau pakan konsentrat akan tetapi ter nak sapi tersebut dipelihara dida lam kandang yang cukup baik yang terbuat dari kayu broti, bera tapkan seng dan berlantaikan semen dan tanah.

\section{DAFTAR PUSTAKA}

Badan pusat statistik (BPS), 2020. Populasi Ternak Sapi di Indonesia. 2 (1): 3-4

Badan Pusat Statistik (BPS), 2020. Populasi Sapi potong di Sumatera Utara. Produksi Daging Sapi di Sumatera Utara. 2 (2): 5

Mutmainah Analisis Kelayakan Usaha Ternak Sapi Potong di Desa Lumpangang Kecamatan Pajukuang Kabupaten Banta eng , 2018. 11 (4): 47-50

Mutmainah Analisis Kelayakan Usaha

Ternak Sapi Potong di Desa Lumpangang Kecamatan Pa'jukuang Kabupaten Banta eng , 2018. 11 (4): 47-50

Trilinardi, A. 2020. Analisis Kontribusi Pendapatan Usaha Ternak Sapi Lokal Terhadap Pendapatan Keluarga Petani Padi Sawah (Studi Kasus: Nagori Tumorang Kecamatan Gunung Maligas Kabupaten Simalungun). Skripsi. Fakultas Pertanian. Universitas Simalungun. 14 (3): 51-57 